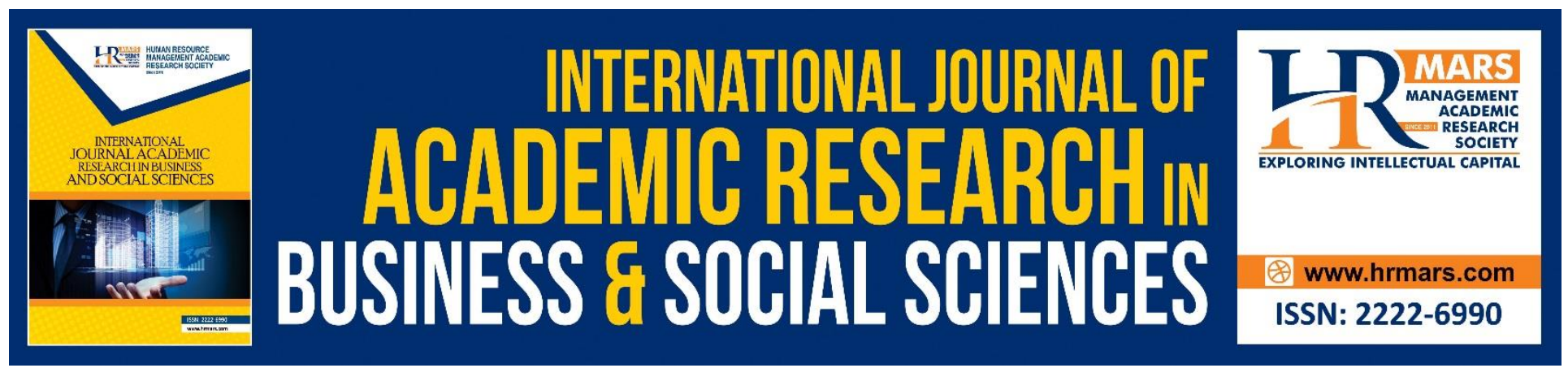

\title{
The Relationship between Social Media and the Level of Ambition, Depressive Symptoms and Anxiety among Secondary School Students in Irbid
}

Yousef Al-Qudah \& Nashaat Baioumy

To Link this Article: http://dx.doi.org/10.6007/IJARBSS/v8-i11/4912

DOI: 10.6007/IJARBSS/v8-i11/4912

Received: 08 Sept 2018, Revised: 13 Oct 2018, Accepted: 16 Oct 2018

Published Online: 28 Nov 2018

In-Text Citation: (Al-Qudah \& Baioumy, 2018)

To Cite this Article: Al-Qudah, Y., \& Baioumy, N. (2018). The Relationship between Social Media and the Level of Ambition, Depressive Symptoms and Anxiety among Secondary School Students in Irbid. International Journal of Academic Research in Business and Social Sciences, 8(11), 397-420.

Copyright: (c) 2018 The Author(s)

Published by Human Resource Management Academic Research Society (www.hrmars.com)

This article is published under the Creative Commons Attribution (CC BY 4.0) license. Anyone may reproduce, distribute, translate and create derivative works of this article (for both commercial and non-commercial purposes), subject to full attribution to the original publication and authors. The full terms of this license may be seen at: $\underline{\text { http://creativecommons.org/licences/by/4.0/legalcode }}$

Vol. 8, No. 11, 2018, Pg. 397 - 420

http://hrmars.com/index.php/pages/detail/IJARBSS

JOURNAL HOMEPAGE

Full Terms \& Conditions of access and use can be found at http://hrmars.com/index.php/pages/detail/publication-ethics 


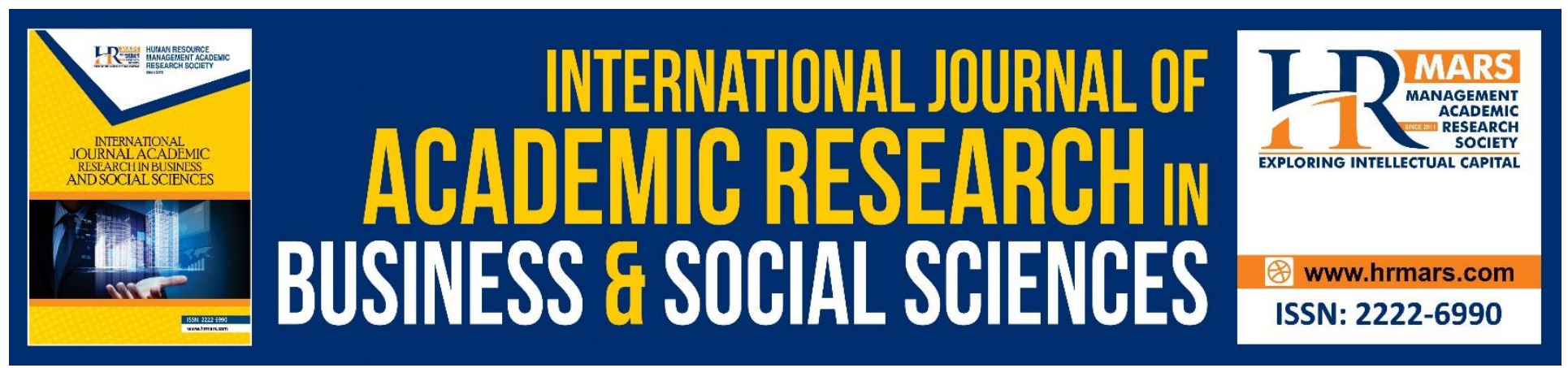

\title{
The Relationship between Social Media and the Level of Ambition, Depressive Symptoms and Anxiety among Secondary School Students in Irbid
}

\author{
Yousef Al-Qudah \& Nashaat Baioumy
}

Faculty of Islamic Contemporary Studies University of Sultan Zainal Abidin, 21300, Terengganu, Malaysia

\section{Abstract}

The various types of social media that contain news and publications play a major role in evoking the emotions of adolescent students, which leads to a strong impact on their emotions and thoughts. Also, the temperaments expressed through social networks are widely contagious. For example, reading a large number of messages from friends may generate negative feelings and this negative effect may increase for secondary school students who spend more than two hours a day on social media which puts them at risk of mental disorders such as depression, anxiety, etc., or could push them toward positive thinking about the future and the ambitions they have. All of this calls for research to understand the nature of these effects, whether negative or positive thus take the right actions as well as to guide the students and support them psychologically. This was the objective of this study. An analytical descriptive approach was applied to investigate the relationship between social media and the level of ambition, depressive symptoms and anxiety among twelfth grade students in a secondary school in Irbid. In this study the researcher used measures for each of the following: 1)the use of social media 2) ambitions 3) the depressive symptoms 4) anxiety. A total of 552 students were selected randomly from twelfth grade students enrolled in a secondary school in Irbid for the academic year $2017 / 2018$. The analysis of the results highlighted a statistically significant positive relationship between the aim of using the account along with engaging in topics of interest on the social networking sites and ambition, a statistically significant positive relationship between the duration of using social networking sites along with engaging in topics of interest on social networking sites and both of depressive symptoms and anxiety, and that this relationship among males is stronger than that of females. The results showed that the duration of use of the account and engaging in topics of interest in the social networking sites indicated approximately $16 \%$ of the variation in the level of ambition. Also, the topics that attract attention on social networking sites and the duration of the use of the account both explained approximately $20 \%$ of the variance in the level of depressive symptoms. Furthermore, the duration of use of the account and the purpose of using the account both accounted for about $15 \%$ of the variation in the level of anxiety. The Study 
INTERNATIONAL JOURNAL OF ACADEMIC RESEARCH IN BUSINESS AND SOCIAL SCIENCES

Vol. 8, No. 11, Nov, 2018, E-ISSN: 2222-6990 @ 2018 HRMARS

recommended that school students should be made aware of the importance of positive interaction in the use of social media, and use it to provide access to opportunities and aspirations of others and to motivate them, In Addition to Clarifying the optimal use of the Social media.

Keywords: Social Media, Ambition, Depressive Symptoms, Anxiety.

\section{Introduction}

The stage of adolescence in general and mid-adolescence in particular has specificity in the life of the individual, which is considered or called the critical stage, in which the individual begins to mature and aspires to achieve a lot of things. The individual's outlook to the future in this stage is ideal, accompanied with the belief that he/she will do such and such and all of this takes place in the imagination, In this period, the ambition is of a high level, the adolescent is aware of his/her abilities and potentials, self-confidence increases with each success, and has a positive perception of himself/herself, which in turn leads to the high level of ambition (Wahab, 1992). Adolescence is viewed as the physical, sexual, emotional and mental maturation, which psychologists consider psychological growth, including also the changes that accompany it during the transition from childhood to adulthood (Qenaoui, 1992).

The stage of adolescence is a production and extension of childhood which is considered important in the life of the individual (Zahrani, 2009). Anxiety, emotional disturbance, loss of selfconfidence and incompatibility are factors that reduce the level of ambition (Al-Thawad, 2002).

The level of ambition reflects the acquired motivations. The individuals differ in their level of ambition, and the circumstances surrounding adolescents play an important role (Zahrani, 2009). Aqel (2003) defines ambition as evidence of individual self-confidence, ranging from ups and downs based on successes and failures. Muawad and Abd al-'Azim (2005) define the ambitious individual as the person who is receptive to everything new, enduring frustrations, able to set goals and optimistic. The pursuit of self-goals is positively related to the mental health of individuals and enhances the satisfaction of basic psychological needs thus is linked to individual happiness and personal growth (Bauer, McAdams \& Sakaeda, 2005). Adler's theory of ambition states that the individual's struggle to attain excellence and growth exists in order to compensate for feelings of inadequacy and struggle or for pursuit of safety. He also emphasized the importance of self and social relations, as well as the importance of the present. He believes that an individual is a social organism driven primarily by social incentives and life goals (Adler, 1998).

The field theory of Levin refers to several factors that act as motives for learning, which are called the level of ambition, which creates new goals after the individual feels the state of satisfaction and self-esteem. These factors are: maturity, success, failure, emotional forces, social forces Competition, peer level, and the individual's view of the future (Lewin, 1939). While Stanger considers the level of ambition to be the best mean to measure personality in the response position. He believes that the assessment of self-image takes place in the frame of the individual reference, which in turn reflects the individual's relationship with the groups. Furthermore, he estimated that adolescents attribute success to the image of self which drives them to pursue a higher ambition than of the current state due to the tendency to reach more idealistic versions of themselves (Stanger, 1961). Modern technological developments in the mid-1990s caused a quantum leap and a real revolution in the world of communication. The international communication network (Internet) was 
spread throughout the globe, connecting parts of this vast world with its vast space and paving the way for all societies to get acquainted and exchange ideas and views. Each browser benefited from this multimedia network which at the time resembled the best means of communication between individuals and groups, and then chat networks emerged such as (Facebook, Twitter, YouTube, Gmail, etc.), which created a kind of social networking and enabled discussion between users. (Mansour, 2012).

Social media are defined as the ways and means by which information and knowledge can be exchanged and sophisticated human relationships are created, including traditional and modern electronic means. Or a system of electronic networks on the Internet that allows the subscriber to create a site of his/her own, and then be linked through an electronic social system with other members of the same interests and hobbies (Jarrar, 2012).

These modern means of communication have many outcomes and benefits to the individual and society in every aspect of life, provided that these means are used positively, but if the use is negative and random, then the consequences can be disastrous and fatal to the individual and society as a whole. These communication means have created incubation for mental illness and self-containment among certain individuals. Despite the wideness of this world and the spread of this technology, the user feels anxious, upset, sad and depressed (Shahri, 2012).

The percentage of users of social media in the Arab countries reached $39 \%$ of the population, while the number of social media users in the Middle East reached 63 million which is 26\%, and $90 \%$ of Internet users in Jordan use social networking sites on a daily basis (Badr, 2016). \%88 of the total number of Internet users in the Middle East have at least one account in a social networking site, and statistics indicate that $65 \%$ of users of social networking sites are males, while females comprise $35 \%$ of the total number of users. As for the age groups, the majority of users of social media are in the 15-20 age group. The age group under the age of 24 is $45 \%$, followed by the $24-34$ age group, constituting 32\%, 11\% for the 35-44 age group. And 12\% for the age group above 44 (Amran, 2013)

Anxiety, depression and poor psychological compatibility are a reason to distract the adolescent's thinking and mind, which causes weakness in performance, a decline in the level of ambition and indifference to reach goals. There is no doubt that the psychological compatibility and emotional balance of the adolescent have a large role in elevating the level of ambition (Alaswad, 2003).

The level of ambition plays an important role in the life of the adolescent, as it is one of the most important dimensions in the human personality, because it is a distinguishing indicator of the adolescent's approach to himself/herself, his environment and society, which determines the adolescent's social activity, relations with others, his acceptance of social norms, self-acceptance and taking responsibility for different roles. The closer the level of ambition to the personal potential the more the adolescent has emotional balance and mental health (Ibrahim, 2003). The socio-economic level plays an important role in shaping the personality of the adolescent, especially his ambition. The improvement in the economic level and the improvement in family income helps to increase the aspiration to a higher level and better positions. Also, the socio-economic level affects the level and type of ambition in a different matter, the high economic level creates a high degree of ambition, and the low socioeconomic level may create motivation towards a higher degree of ambition, because it 
sharpens the person's determination to challenge the circumstances by overcoming them and demonstrating his/her abilities (Al-Tuwaijri, 2002).

Individuals from economically and socially stable households are more likely than others to develop high levels of ambition and ability to reach them. Low-aspiring adolescents often belong to a low social and economic environment and are more socially and economically stressed than adolescents with high ambitions. Social factors, whether education, university culture, the annual income of the family and the expected increase in the annual income of the father is of great importance and affects the adolescent's effort, desire, ambition and achievement (Suleiman, 1984).

The most important features of this stage is characterized by the increase of social development in a remarkable manner, and it often appears in the following manifestations: 1 . Adolescent sense of social responsibility, and the tendency to help others. 2 - Interest in the other sex, and appear in the form of tendencies and interest in making friends. 3. Choosing friends from individuals with whom they tend to make connections. 4. The tendency for leadership and clarity of attitudes and tendencies of the adolescent (Kadhafi, 2000). Several studies have shown that social media have serious consequences for the individual, the family and the community. Long hours using these means causes individuals in general and adolescents in particular to become isolated and away from reality and inclined towards introversion, thus making people live in a world of their own. Leading them to fall prey to various mental disorders, primarily depression, anxiety and alienation (Al-Majali, 2007; Becker, Alzahabi \& Hopwood, 2013; Strickland, 2014).

Depression is the most common psychological symptom caused by social media. It is a common symptom in all mental and neurological situations, but depression as a neurological disease is a transient condition that occurs as a result of some traumatic events. It occurs as an attempt by the individual to alleviate his acute anxiety and is accompanied by a decline in self-worth (Al-Tayeb, 1994). Most definitions in psychology agree that depression is a state of emotional disturbance characterized by low mood of the individual and the emergence of psychological changes such as loneliness, introversion, insomnia, physical changes such as body weight change, sluggishness and slow response (Beck \& Emery, 1985).

Beck (1991) considers depression to be a mood disorder more than anything else that results from erroneous thinking patterns and is thought to be the result of the individual's way of handling information and how he interprets events, his beliefs, and his negative perception of the self, the world, and the future. Beck believes there are three types of attitudes that can be enough to trigger depression:

- Attitudes that decrease the self-esteem of the individual.

- Attitudes that include impeding the achievement of the individual goals that are important to $\mathrm{him} /$ her, or impose circumstances and situations that the individual cannot resolve.

- Attitudes leading to physical deterioration and disease.

Rude. \& Pennebaker (2004) point out that social media have revealed and predicted many emotional disorders, most notably depressive symptoms and low mood, which is the loss of interest or pleasure in activities. Park, Cha and Cha (2012) note that mood is one of the most important behavioral traits caused by social media.

As for mood, depressed people suffer from distress, feeling down, despair, hopelessness, inability to enjoy, and loss of desire to practice their daily activities. As for appearance and movement, 
the depressed is suffering from neglect in elegance and appearance. Clothes tend to have dark colors. Facial expressions tend to stifle and stiff, and there is often a motor slowdown. The speech is slow. It may be accompanied by many stops and slow responses. The imdividual may take time to answer a simple question (Barlow, 1999).

Depression patients suffer from insomnia and few hours of sleep, however, some sleep longer than normal sleeping hours. Psychological studies have shown that depression is accompanied by a marked increase in activity that regulates sleep, appetite, attention, gender, glands in the central nervous system (Tayeb, 1994). As for psychotic symptoms, depressed people may feel things that do not exist in their bodies. The depressed person sees the image of his funeral and his grave, or listens to those who reproach and belittle him/her, and who invites him/her to commit suicide (Myers, 2000). Banyai et al., 2017 and Lin et al. (Lin et al., 2016) point to the fact that high use of social media increases the level of depressive symptoms.

Andersen et al. (2016) and Pantic et al. (2012) note that there is a positive and significant relationship between use, depression and anxiety. Becker et al. (2013) note that social media are a risk factor for anxiety-related mental health problems. The greater the use of these means, the greater the symptoms of anxiety in individuals. Ophir, Nass \& Wagner (2009) noted that the use of social media was associated with mental health in general and depression and anxiety in particular.

Anxiety is defined as an internal emotional response without a threatening external cause, which means that the response is triggered internally in the individual. Anxiety may be associated with an external situation that is not dangerous, so that the individual is afraid of an unknown or unidentified cause (Walker \& Roberts, 1983). And anxiety is linked and diverges with other concepts, many studies have indicated that depression is a factor most related to anxiety (Fridman, 2003).

There is an impact to anxiety on the performance of the individual, which may be the opposite if anxiety exceeds over a certain level of motivation of the individual, as defined by the law "focus Didson" in the relationship between anxiety and performance as the law shows that the greater the anxiety is the higher the performance is to a certain extent. This kind of anxiety is average therefore allows the highest level of performance. If the anxiety is too high that it exceeds the average, the performance reaches zero (Al-Tayeb, 1994)

Woods (2015) points out the impact of social media on many aspects of adolescent life, such as sleep quality, self-confidence, anxiety, depression, and emotional investment. It is very important to understand the relationship between social media, anxiety and lack of sleep in adolescent years, and the impact of social media means on their health. Al-Muzaffar (2015) believes that there are many problems experienced by twelfth grade students because this period is considered a transition from childhood to adulthood. The most important problems are the following:

1. Physical and health problems: adolescents in secondary school are exposed or feel different health conditions. The most important reasons are that they suffer from psychological problems and emotional states because in this period physiological and emotional changes occur affecting all aspects of the individual's personality.

2. School problems: The most important of these problems are thinking a lot about obtaining high grades, fear of failing, fear of exams, and the difficulty in understanding textbooks

3. Family problems: the adolescent faces family problems more than the child and the adult because of his desire for independence on the one hand, and his desire to stay obedient and maintain the 
rules of behavior on the other hand, as well as maintaining the culture and the economic, social and health status.

4. Economic Problems: The student's economic problems sometimes arise from the fact that he or she needs to enjoy as his peers with things that may not be available because of his/her family's economic situation or because of their lifestyle. It may also arise from his future expectations of work, career, failure, success, disability or death. Also the relationship and links between these aspects.

5. Social problems: The problems and ideological and psychological changes that the adolescent suffers from are reflected clearly and have an impact on his social relations with his peers and friends in school and on participation in school activities.

While the twelfth grade students in Jordan suffer from many problems that affect their level of education, and these problems are as follows:

1. The weakness of moral, religious and social values of twelfth grade students and the consequent violence and misconduct.

2. The absence of a good example from parents or teachers.

3. The disintegration of the family and preoccupation with joys of life. In addition to the parent's abandonment of their primary role in upbringing and providing advice and guidance to their children at this sensitive stage.

4. Excessive spoiling and intense discipline lead to students falling into such problems.

5. Watching satellite channels containing crime and sex films, and accessing downstream magazines.

6. The negative use of the Internet, and addiction to it.

7. Accompanying bad crowds.

8. The behavior of some bad secondary school teachers and their inappropriate behaviors that negatively affects students.

9. Economic burdens due to higher private tutoring costs for secondary school students (Dagher, 2010).

\section{The problem of the study and its questions}

The various types of social media are the things that stir the emotions of some individuals, which leads to affect the emotions of others. The moods expressed on social networks are widespread therefore reading a large number of messages from friends may generate negative emotions and a feeling that they are manipulating your emotions. The negative impact on secondary school students who spend more than two hours a day on social media can increase their risk of mental disorders such as depression, anxiety, etc., or drive them to think about the future and ambition they seek. Leading them to the need for greater psychological support. Users of social media compare their lives with the moments of happiness that friends on these networks share. This gives them the sense that their lives are less interesting and exciting and more monotonous than others' ideal lives, and thus cause them depression, frustration and even anger and jealousy. Becker et al. (2013) points out that social media are a risk factor for problems Psychological health. Twelfth grade students in Jordan suffer from a number of problems that affect their level of education, including the negative use of the Internet and their addiction to it, including the use of social media, and this may create many psychological problems among students (Dagher, 2010). Based on this, the aim of the current study is investigating the relationship between social media and the level of ambition, depressive 
symptoms and anxiety among secondary school students in Irbid and then answer the following questions:

1. What is the statistical relationship between the use of social media and the level of ambition among a sample of twelfth grade students in Irbid?

2. What is the statistical relationship between social media and the depressive symptoms among a sample of twelfth grade students in Irbid?

3. What is the statistical relationship between social media and anxiety among a sample of secondary school students in Irbid?

4. What is the contribution of social media in predicting the level of ambition of a sample of twelfth grade students in Irbid?

5. To what extent did the social media contribute to predicting depressive symptoms among a sample of twelfth grade students in Irbid?

6. To what extent did social media contribute to predicting anxiety among a sample of twelfth grade students in Irbid?

\section{Objectives of the study}

1. To identify the relationship between social media and the level of ambition and whether it is statistically significant among adolescents of twelfth grade students in Irbid.

2. To identify the relationship between social media and depressive symptoms and whether it is statistically significant among adolescents of twelfth grade students in Irbid.

3. To identifying the relationship between the means of social communication and anxiety and whether it is a statistically significant among adolescents of twelfth grade students in Irbid.

4. To identify the contribution of social media in predicting the level of ambition among adolescents of twelfth grade students in Irbid.

5. To identify the contribution of social media in the prediction of depressive symptoms among adolescents of twelfth grade students in Irbid.

6. To identify the contribution of social media in the prediction of anxiety among adolescents of twelfth grade students in Irbid.

\section{The Importance of the Study}

The theoretical importance of this study is to shed light on the relationship between social media use and the level of ambition, depressive symptoms and anxiety among secondary school students. As well as identifying the extent to which social media are utilized in the different applied fields. Furthermore, to identify how spread social media use is among secondary school students, and whether the level of ambition and depressive symptoms and anxiety is different due to their use of social media.

In terms of practicality, the study provides secondary school students in Jordan with concepts and information related to the importance of modern communication means (social media) and their relation to the level of ambition, depressive symptoms and anxiety. Also it informs the teachers on the importance of modern social communication methods for secondary school students and recommends trying to benefit from it in the educational process. In addition to that, it provides psychological counseling staff in Jordan with information and additional results related to the 
importance of modern communication means (social media) and their relation to the level of ambition, depressive symptoms and anxiety among secondary school students in order to design instructional plans to support and develop the attitudes of students towards the use of modern technologies,

As well as providing parents and decision-makers in Jordan with concepts, information and additional results regarding the importance of modern communication methods (social media) and their relationship to the level of ambition, depressive symptoms and anxiety among secondary school students, in order to help them develop programs and services that are in the best interest of students and suitable for this stage.

\section{Methodology of the Study}

The current study followed the analytical descriptive approach. The study examined the relationship between social media and the level of ambition, depressive symptoms, and anxiety among secondary school students in Irbid.

\section{Study population}

The study population was composed of adolescents from twelfth grade students in a secondary school in Irbid, Jordan, who were in Irbid governorate during the year 2017/2018. The age range of the students was $16-18$ years.

\section{The study sample}

The sample was randomly selected from twelfth grade adolescents in a secondary school in Irbid. The study sample consisted of (552) students (276 males and 276 females).

\section{Study Tools}

The researcher used the following measures:

1. A questionnaire to indicate the number of times and hours of use of social media.

2. The scale of ambition: It is measured by Kasser \& Ryan (2000) scale for ambition, which consists of (35) paragraphs, that were modified by the researcher to suit the twelfth grade students.

3. Depressive symptom scale: It is measured through (Beck)'s depression list which consists of (21) paragraphs, that were modified by the researcher to suit the twelfth grade students.

4. Anxiety scale: It is measured by the Taylor scale (Tayloe, 1951) which consists of (35) paragraphs that were modified by the researcher to suit the twelfth grade students.

\section{Study Results}

The study results related to the relationship between the social media use and the level of aspiration, anxiety and depressive symptoms among second - secondary students in Irbid will be presented. 
INTERNATIONAL JOURNAL OF ACADEMIC RESEARCH IN BUSINESS AND SOCIAL SCIENCES Vol. 8, No. 11, Nov, 2018, E-ISSN: 2222-6990 @ 2018 HRMARS

\begin{tabular}{|c|c|c|c|}
\hline \multicolumn{4}{|c|}{ Table (4 - 1) } \\
\hline \multirow{2}{*}{ Number of Accounts } & Total Number & \multicolumn{2}{|c|}{ Number according to Gender } \\
\cline { 3 - 4 } & & Males & Females \\
\hline One Account & 143 & 69 & 74 \\
\hline Two Accounts & 202 & 97 & 105 \\
\hline $3-6$ Accounts & 185 & 89 & 96 \\
\hline $6-7$ Accounts & 22 & 10 & 12 \\
\hline Total & 552 & 265 & 287 \\
\hline
\end{tabular}

Figure (4 - 1)

Extent of Ownership of Social Media Sites

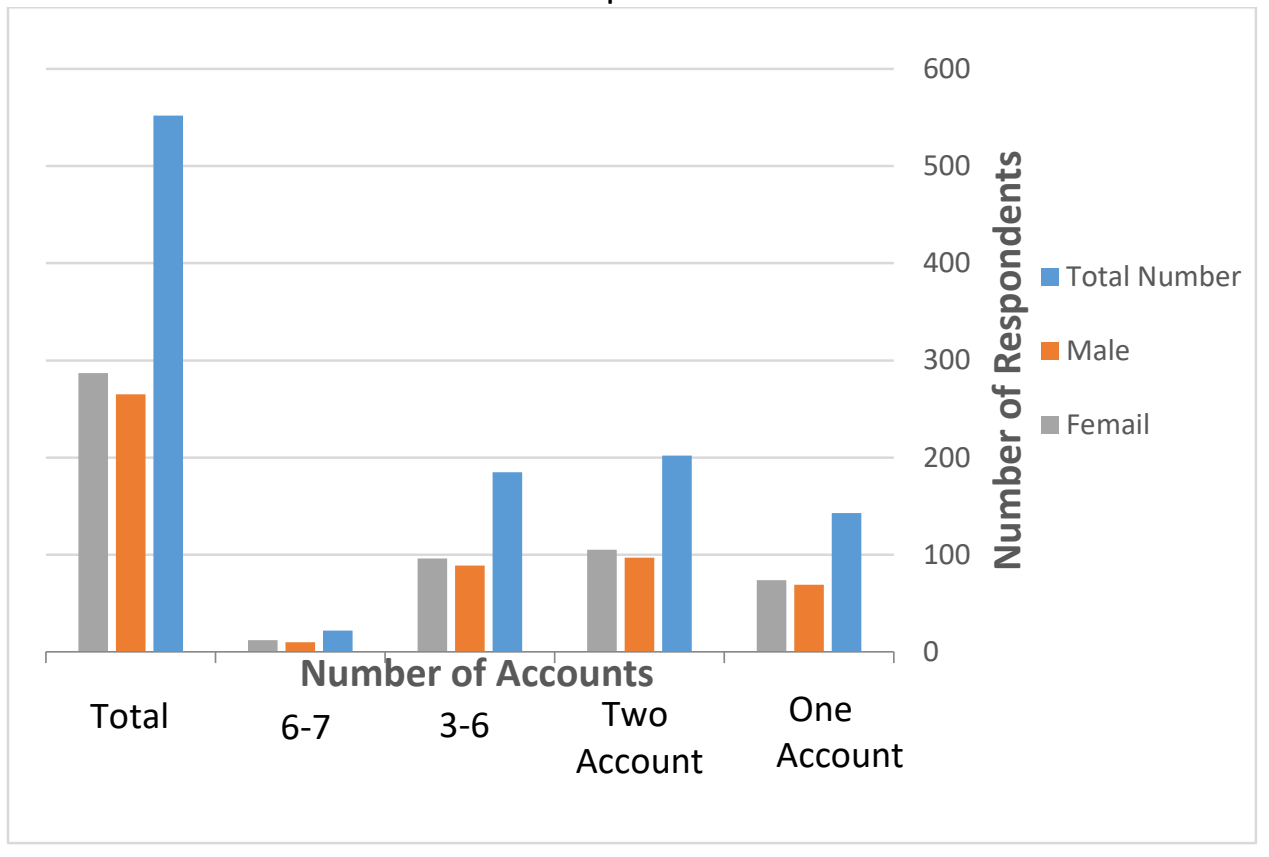

Table (4 - 1) shows that the majority of second - secondary students use two accounts, while the minority use 6 - 7 accounts. This is higher among females than males.

\begin{tabular}{|c|c|c|c|}
\hline \multicolumn{4}{|c|}{ Table (4 - 2) } \\
\hline \multirow{2}{*}{ Number of Accounts } & Total Number & \multicolumn{2}{|c|}{ Number according to Gender } \\
\cline { 3 - 4 } & & Males & Females \\
\hline Less than 2 Hours a day & 127 & 61 & 66 \\
\hline $2-4$ Hours a day & 208 & 100 & 108 \\
\hline More than 4 Hours a day & 217 & 104 & 113 \\
\hline Total & 552 & 265 & 287 \\
\hline
\end{tabular}


INTERNATIONAL JOURNAL OF ACADEMIC RESEARCH IN BUSINESS AND SOCIAL SCIENCES

Figure (4 - 2)

Duration of Social Media Usage

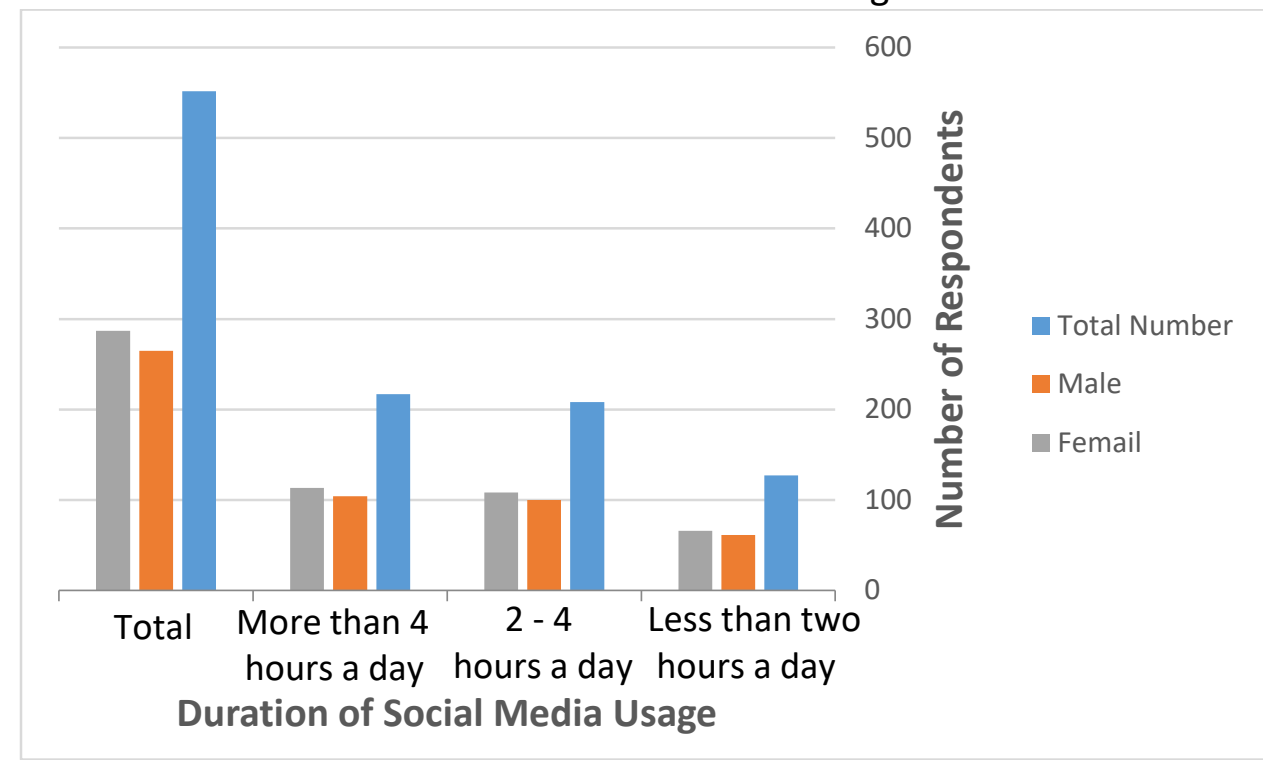

Table (4 - 2) shows that the majority of second - secondary students use social media sites for more than 4 hours a day, while the minority use them for less than two hours a day. This is higher among females than males.

\begin{tabular}{|l|c|c|c|}
\hline \multicolumn{4}{|c|}{ Table (4 - 3) } \\
\hline \multicolumn{1}{|c|}{ Number of Accounts } & Total Number & \multicolumn{2}{|c|}{ Number according to Gender } \\
\cline { 2 - 4 } & & Males & Females \\
\hline $\begin{array}{l}\text { Communicating with my } \\
\text { family. }\end{array}$ & 248 & 101 & 147 \\
\hline $\begin{array}{l}\text { Communicating with my } \\
\text { friends. }\end{array}$ & 303 & 168 & 85 \\
\hline Making new friends. & 198 & 113 & 109 \\
\hline $\begin{array}{l}\text { Improving my learning skills. } \\
\text { Learning about different } \\
\text { cultures. }\end{array}$ & 193 & 84 & 52 \\
\hline $\begin{array}{l}\text { Consuming time and } \\
\text { eliminating boredom. }\end{array}$ & 39 & 37 & 12 \\
\hline $\begin{array}{l}\text { Escaping duties and study } \\
\text { burdens. }\end{array}$ & 60 & 21 & 22 \\
\hline $\begin{array}{l}\text { I feel getting rid of anxiety } \\
\text { when using social media. }\end{array}$ & 27 & 38 & 11 \\
\hline
\end{tabular}


INTERNATIONAL JOURNAL OF ACADEMIC RESEARCH IN BUSINESS AND SOCIAL SCIENCES Vol. 8, No. 11, Nov, 2018, E-ISSN: 2222-6990 @ 2018 HRMARS

\begin{tabular}{|l|c|c|c|}
\hline $\begin{array}{l}\text { I feel getting rid of } \\
\text { depression when using social } \\
\text { media. }\end{array}$ & 31 & 13 & 18 \\
\hline $\begin{array}{l}\text { Increasing my motivation to } \\
\text { study through browsing } \\
\text { news, scientific information, } \\
\text { or honor students news. }\end{array}$ & 18 & 6 & 12 \\
\hline $\begin{array}{l}\text { Seeing the news of the poor } \\
\text { student performance and } \\
\text { their justification for this } \\
\text { performance. }\end{array}$ & 11 & 5 & 6 \\
\hline
\end{tabular}

Figure (4 - 3)

Purpose of Social Media Usage

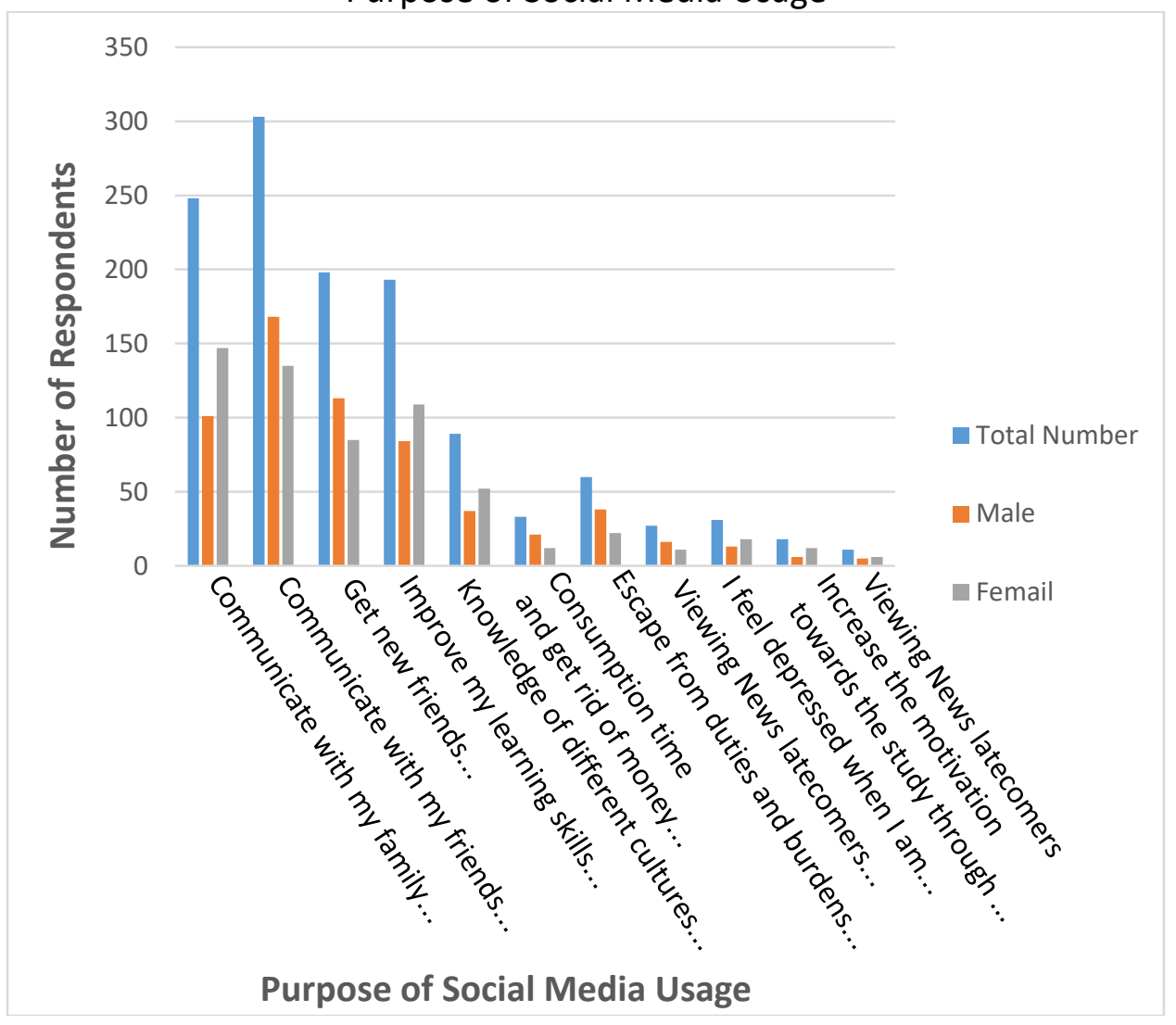

Table (4 - 3) shows that the majority of second - secondary students use social media sites to communicate with friends, which is higher among males than females, while the minority use them to see the news of the poor student performance and their justification for this performance, which is higher among females than males. 
INTERNATIONAL JOURNAL OF ACADEMIC RESEARCH IN BUSINESS AND SOCIAL SCIENCES Vol. 8, No. 11, Nov, 2018, E-ISSN: 2222-6990 @ 2018 HRMARS

\begin{tabular}{|l|c|c|c|}
\hline \multicolumn{4}{|c|}{ Table (4 - 4) } \\
\hline \multicolumn{2}{|c|}{ Topics Attracting the Attention of Sample to Social Media Sites } \\
\cline { 2 - 4 } & Total Number & Number according to Gender \\
\cline { 2 - 4 } & & Males & Females \\
\hline Educational Topics & 204 & 92 & 112 \\
\hline Social Topics & 270 & 107 & 163 \\
\hline Political Topics & 32 & 19 & 52 \\
\hline Sports Topics & 210 & 158 & 106 \\
\hline Scientific and Cultural Topics & 198 & 92 & 29 \\
\hline $\begin{array}{l}\text { News of Disasters and } \\
\text { Accidents }\end{array}$ & 66 & 37 & 91 \\
\hline Success Stories in Life & 155 & & 56 \\
\hline Failure Stories in life & 88 & 32 & \\
\hline
\end{tabular}

Figure (4 - 4)

Topics Attracting the Attention of Sample to Social Media Sites

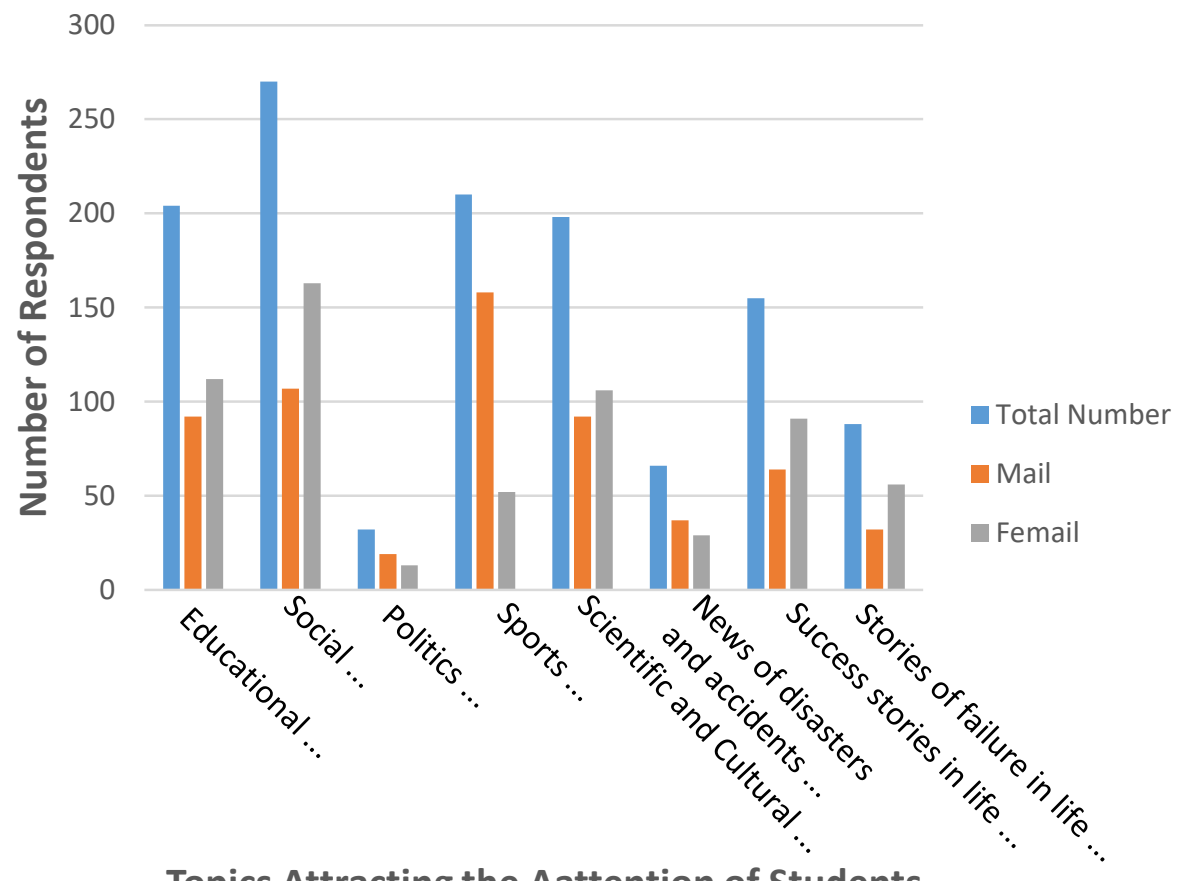

Topics Attracting the Aattention of Students

Table $(4-4)$ shows that the majority of second - secondary students use social media sites for social topics, which is higher among females than males, while the minority use them for political topics, which is higher among males than females. 
INTERNATIONAL JOURNAL OF ACADEMIC RESEARCH IN BUSINESS AND SOCIAL SCIENCES Vol. 8, No. 11, Nov, 2018, E-ISSN: 2222-6990 @ 2018 HRMARS

First Question: What is the statistical relationship between the social media and the aspiration level among a sample of second - secondary students in Irbid?

For the purpose of answering this question, the following hypothesis was formulated: "There is a positive correlation between the social media use and the aspiration level among a sample of second - secondary students in Irbid ".

To answer this question, Pearson correlation coefficients were calculated between the sample scores on each dimension of the social media scale and their scores on the aspiration scale, as shown in Table (4-5).

\begin{tabular}{|l|l|l|l|}
\hline \multicolumn{4}{|c|}{ Table (4 - 5) } \\
\hline \multicolumn{4}{|c|}{$\begin{array}{l}\text { Correlation Coefficients between the Sample Scores on each Dimension of the Social Media } \\
\text { Scale and their Scores on the Aspiration Scale }\end{array}$} \\
\hline Dimensions & Total Sample & Males & Females \\
\hline Account Ownership on Social Media Sites & 0.04 & $0.15^{*}$ & -0.09 \\
\hline Duration of Social Media Usage & 0.06 & -0.01 & $0.12^{*}$ \\
\hline $\begin{array}{l}\text { Purpose of Using an Account on Social Media } \\
\text { Sites }\end{array}$ & $0.34^{* *}$ & $0.38^{* *}$ & $0.30^{* *}$ \\
\hline $\begin{array}{l}\text { Topics Attracting my Attention on Social Media } \\
\text { Sites }\end{array}$ & $0.24^{* *}$ & $0.32^{* *}$ & $0.15^{*}$ \\
\hline Total Scale & $0.36^{* *}$ & $0.46^{* *}$ & $0.27^{* *}$ \\
\hline
\end{tabular}

\section{$0.05>\mathrm{P} * ; 0.01>\mathrm{P} * *$}

Table ( 4 - 5) shows that there is a statistically significant positive relationship between the dimensions (the purpose of using an account and the topics attracting my attention) and the aspiration, and that this relationship is stronger among males than females. Males are associated with the account ownership on social media sites and females are associated with the duration of social media usage. The hypothesis is accepted according to the results. Table (4 - 6) shows the sample responses to the aspiration scale options.

\begin{tabular}{|l|l|l|l|l|l|l|}
\hline \multicolumn{7}{|c|}{ Sable (4 - 6) } \\
\hline Somple Response Rate to Aspiration Scale & Never & Rarely & Sometimes & Often & Always \\
\hline 1 & Academic Excellence & 156.7 & 133.6 & 68 & 77.9 & 163.7 \\
\hline 2 & Study Perseverance & 159.7 & 173.8 & 246.8 & 210 & 39.7 \\
\hline 3 & Growth and Personal Confidence & 171.3 & 226.5 & 169.4 & 95 & 138.1 \\
\hline 4 & Mental Health & 225.7 & 178.7 & 251.3 & 112.4 & 132 \\
\hline 5 & $\begin{array}{l}\text { Taking Responsibility and Self - } \\
\text { Reliance }\end{array}$ & 80.1 & 49.8 & 100.9 & 113.5 & 55.7 \\
\hline 6 & Relationships and Personal Status & 131 & 96.6 & 118.9 & 84.2 & 69.4 \\
\hline 7 & Study Outlook & 93.9 & 121.8 & 58.2 & 49.3 & 76.7 \\
\hline
\end{tabular}


INTERNATIONAL JOURNAL OF ACADEMIC RESEARCH IN BUSINESS AND SOCIAL SCIENCES

Figure (4 - 5)

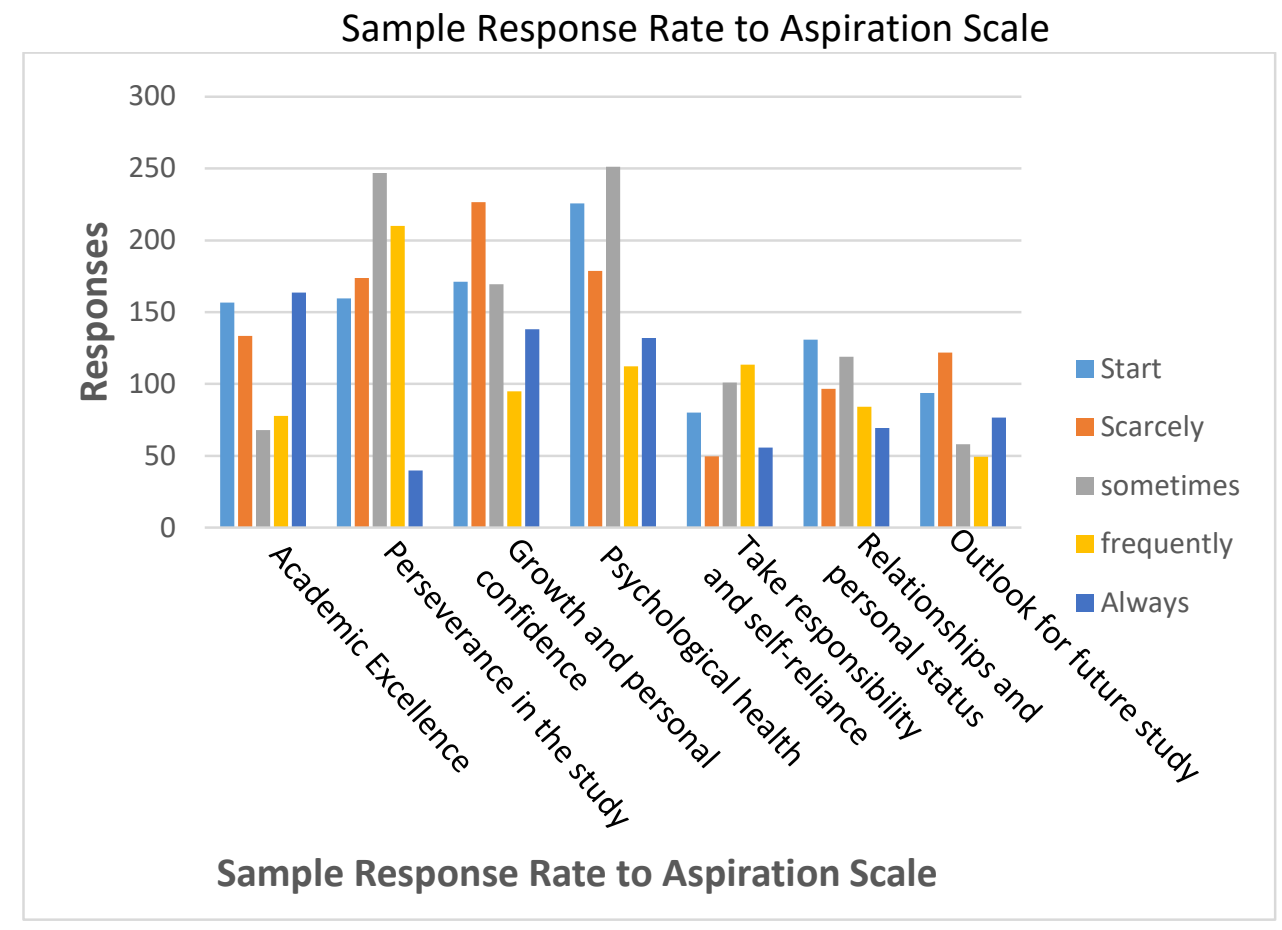

Table (4 - 6) shows that the highest response rate of second - secondary students to (always) is in academic excellence Their responses to (often) are in taking responsibility and self - reliance. Their responses to (sometimes) are in study perseverance as well as relationships and personal status. Their responses to (rarely) are in growth and personal confidence as well as study outlook. Eventually, their responses to (never) are in mental health.

Second Question: What is the statistical relationship between the social media and the depressive symptoms among a sample of second - secondary students in Irbid?

For the purpose of answering this question, the following hypothesis was formulated: "There is an inverse correlation between the social media use and the depressive symptoms among a sample of second - secondary students in Irbid ".

To answer this question, Pearson correlation coefficients were calculated between the sample scores on each dimension of the social media scale and their scores on the depressive symptoms scale, as shown in Table (4 - 7). 
INTERNATIONAL JOURNAL OF ACADEMIC RESEARCH IN BUSINESS AND SOCIAL SCIENCES Vol. 8, No. 11, Nov, 2018, E-ISSN: 2222-6990 @ 2018 HRMARS

Table (4 - 7)

Correlation Coefficients between the Sample Scores on each Dimension of the Social Media Scale and their Scores on the Depressive Symptoms Scale

\begin{tabular}{|l|c|c|c|}
\hline Dimensions & Total Sample & Males & Females \\
\hline Account Ownership on Social Media Sites & 0.04 & 0.08 & 0.01 \\
\hline Duration of Social Media Usage & $-0.10^{*}$ & $-0.14^{*}$ & -0.08 \\
\hline $\begin{array}{l}\text { Purpose of Using an Account on Social Media } \\
\text { Sites }\end{array}$ & 0.01 & -0.03 & 0.05 \\
\hline $\begin{array}{l}\text { Topics Attracting my Attention on Social Media } \\
\text { Sites }\end{array}$ & $0.42^{* *}$ & $0.43^{* *}$ & $0.41^{* *}$ \\
\hline Total Scale & $0.20^{* *}$ & $0.19^{* *}$ & $0.20^{* *}$ \\
\hline
\end{tabular}

\section{$0.05>\mathrm{P} * ; 0.01>\mathrm{P} * *$}

Table ( 4 - 7) shows that there is a statistically significant positive relationship between the dimensions (the duration of social media usage and the topics attracting my attention) and the depressive symptoms, and that this relationship is stronger among males than females. According to the results, the hypothesis is accepted regarding the dimension of (duration of social media usage) and rejected regarding the dimension of (topics attracting my attention). With regard to other dimensions, the table shows that there is no relationship between them and depressive symptoms. Table (4 - 8) shows the sample responses to the depression scale options.

\begin{tabular}{|l|l|c|c|c|c|c|}
\hline \multicolumn{7}{|c|}{ Table (4 - 8) } \\
\hline \multicolumn{9}{|c|}{ Sample Response Rate to Depressive Symptoms Scale } \\
\hline No. & Dimensions & Never & Rarely & Sometimes & Often & Always \\
\hline 1 & Sadness & 53.6 & 73.5 & 51.1 & 87.6 & 134 \\
\hline 2 & Pessimism & 50.4 & 95.6 & 79.7 & 75.1 & 99.2 \\
\hline 3 & Failure Sense & 97.7 & 69.6 & 58.5 & 53.3 & 121.1 \\
\hline 4 & Dissatisfaction & 57.2 & 109.7 & 57.3 & 88.9 & 86.8 \\
\hline 5 & Guilt Feeling & 81.5 & 44.1 & 77.2 & 85.1 & 112.3 \\
\hline 6 & Punishment Expectancy & 53.1 & 87.5 & 87 & 80.3 & 92.2 \\
\hline 7 & Self - hatred & 97.9 & 89.5 & 55.1 & 45.3 & 112.2 \\
\hline 8 & Self - blame & 74.3 & 64.3 & 85.7 & 51.5 & 124.3 \\
\hline 9 & Suicidal Thoughts & 80.1 & 88.9 & 80.3 & 79 & 71.7 \\
\hline 10 & Crying & 118.3 & 59.4 & 67.3 & 75.8 & 79.2 \\
\hline 11 & Irritability & 72.7 & 112.9 & 66.7 & 65.5 & 82.4 \\
\hline 12 & Social Withdrawal & 76.7 & 90.8 & 58.6 & 91.7 & 82.2 \\
\hline 13 & Hesitation and Indecisiveness & 68.9 & 100.9 & 64.7 & 95.3 & 70.3 \\
\hline 14 & Mental Image of the physical Appearance & 68.3 & 92.7 & 70.6 & 92.9 & 75.3 \\
\hline 15 & Inability to Work & 57.1 & 95.5 & 82.3 & 54.8 & 110.6 \\
\hline 16 & Difficulty Falling Asleep & 69.8 & 69.8 & 69.6 & 65.5 & 125.5 \\
\hline 17 & Tiredness & 76.7 & 90.8 & 58.6 & 91.7 & 82.2 \\
\hline 18 & Appetite Loss & 77.9 & 106.2 & 90.3 & 58 & 67.8 \\
\hline 19 & Weight Loss & 81.5 & 89.1 & 96.4 & 56.2 & 76.7 \\
\hline
\end{tabular}


INTERNATIONAL JOURNAL OF ACADEMIC RESEARCH IN BUSINESS AND SOCIAL SCIENCES Vol. 8, No. 11, Nov, 2018, E-ISSN: 2222-6990 @ 2018 HRMARS

\begin{tabular}{|l|l|l|l|l|l|l|}
\hline 20 & Health Concerns & 51.5 & 72.9 & 87.9 & 54.8 & 133.2 \\
\hline
\end{tabular}

Figure (4 - 6)

Sample Response Rate to Depressive Symptoms Scale

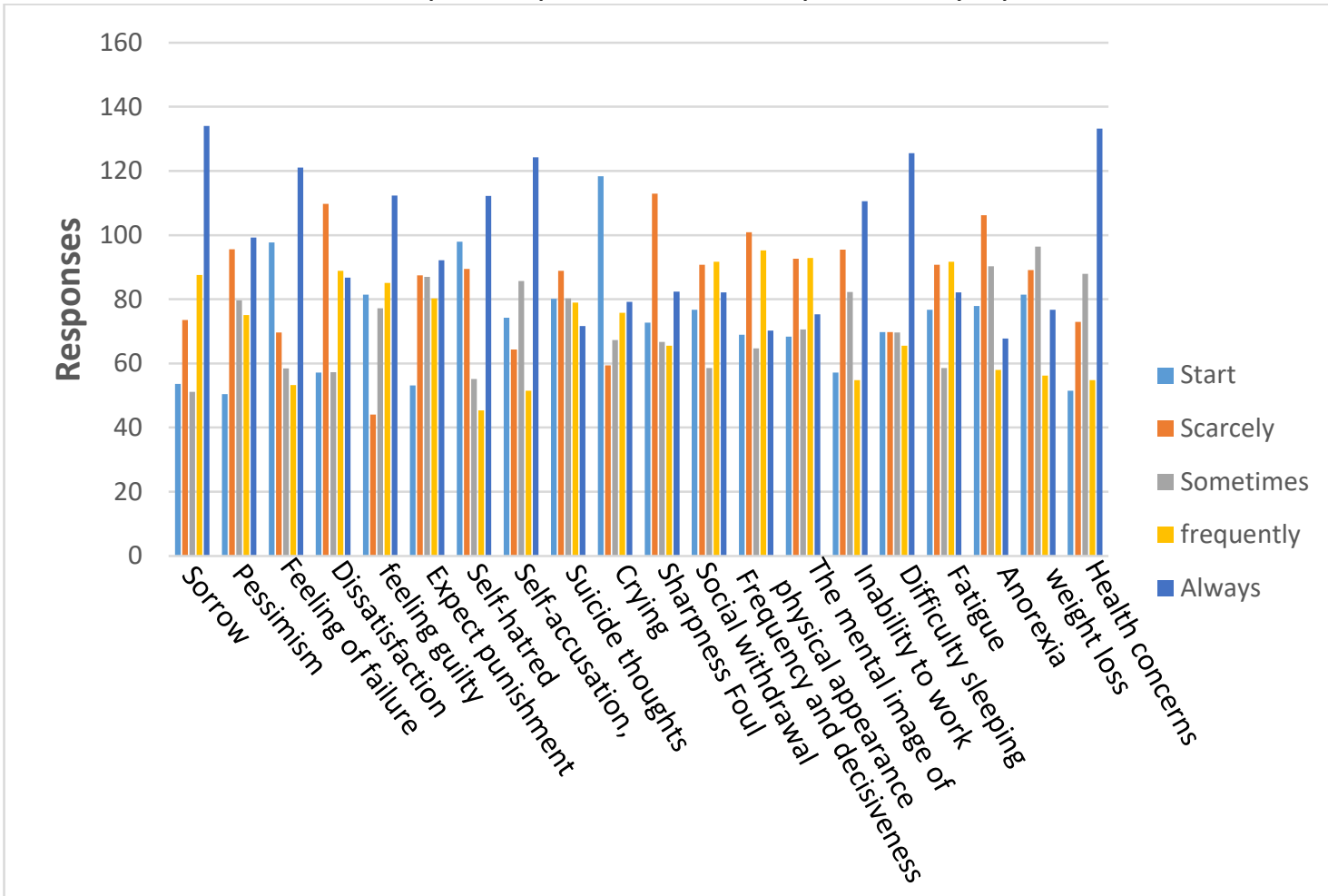

Sample Response Rate to Depressive Symptoms Scale

Table (4 - 8) shows that the highest response rate of second - secondary students to (always) is in pessimism, failure sense, guilt feeling, punishment expectancy, self - hatred, self - blame, inability to work, difficulty falling asleep and health concerns. Their responses to (often) are in sadness, social withdrawal, mental image and tiredness. Their responses to (sometimes) are in weight loss. Their responses to (rarely) are in dissatisfaction, suicidal thoughts, irritability, hesitation and indecisiveness, and appetite loss. Eventually, their responses to (never) are in crying.

Third Question: What is the statistical relationship between the social media and the level of anxiety among a sample of second - secondary students in Irbid?

For the purpose of answering this question, the following hypothesis was formulated: "There is an inverse correlation between the social media use and the anxiety among a sample of second secondary students in Irbid ".

To answer this question, Pearson correlation coefficients were calculated between the sample scores on each dimension of the social media scale and their scores on the anxiety scale, as shown in Table (4 - 9). 
INTERNATIONAL JOURNAL OF ACADEMIC RESEARCH IN BUSINESS AND SOCIAL SCIENCES Vol. 8, No. 11, Nov, 2018, E-ISSN: 2222-6990 @ 2018 HRMARS

\begin{tabular}{|l|c|c|c|}
\hline \multicolumn{4}{|c|}{ Table (4 - 7) } \\
\hline \multicolumn{4}{|l|}{$\begin{array}{l}\text { Sorrelation Coefficients between the Sample Scores on each Dimension of the Social Media } \\
\text { Scale their Scores on the Anxiety Scale }\end{array}$} \\
\hline Dimensions & Total Sample & Males & Females \\
\hline Account Ownership on Social Media Sites & 0.03 & 0.02 & 0.05 \\
\hline Duration of Social Media Usage & $0.35^{* *}$ & $0.38^{* *}$ & $0.33^{* *}$ \\
\hline $\begin{array}{l}\text { Purpose of Using an Account on Social Media } \\
\text { Sites }\end{array}$ & $0.16^{* *}$ & $0.26^{* *}$ & 0.07 \\
\hline $\begin{array}{l}\text { Topics Attracting my Attention on Social Media } \\
\text { Sites }\end{array}$ & 0.02 & 0.08 & -0.02 \\
\hline Total Scale & $0.24^{* *}$ & $0.33^{* *}$ & $0.16^{* *}$ \\
\hline
\end{tabular}

$0.05>\mathrm{P} * ; 0.01>\mathrm{P} * *$

Table ( 4 - 9) shows that there is a statistically significant positive relationship between the dimensions (the duration of social media usage and the topics attracting my attention) and the anxiety, and that this relationship is stronger among males than females. The hypothesis is rejected according to the results. With regard to other dimensions, the table shows that there is no relationship between them and anxiety. Table (4 - 10) shows the sample responses to the anxiety scale options.

\begin{tabular}{|l|l|c|c|c|c|c|}
\hline \multicolumn{7}{|c|}{ Sable (4 - 10) } \\
\hline Nomple Response Rate to Anxiety Scale & Dimensions & Never & Rarely & Sometimes & Often & Always \\
\hline 1 & School and Health Anxiety & 211.9 & 303.8 & 249.1 & 217.7 & 317.6 \\
\hline 2 & Exam Anxiety & 99.1 & 106.8 & 149.5 & 194.4 & 150.4 \\
\hline 3 & Fear and Anxiety of Failure & 102.9 & 81.6 & 157.1 & 84.8 & 73.9 \\
\hline 4 & $\begin{array}{l}\text { Anxiety of Emotional and Physical } \\
\text { Problems }\end{array}$ & 185 & 144.1 & 268.5 & 143.8 & 158.5 \\
\hline 5 & $\begin{array}{l}\text { Anxiety of Memory and } \\
\text { Memorization Problems }\end{array}$ & 63.1 & 111.7 & 81.7 & 78.1 & 65.4 \\
\hline 6 & Excellence Anxiety & 51.1 & 136.1 & 80.6 & 79.9 & 52.3 \\
\hline
\end{tabular}


INTERNATIONAL JOURNAL OF ACADEMIC RESEARCH IN BUSINESS AND SOCIAL SCIENCES

Figure (4 - 7)

Sample Response Rate to Anxiety Scale

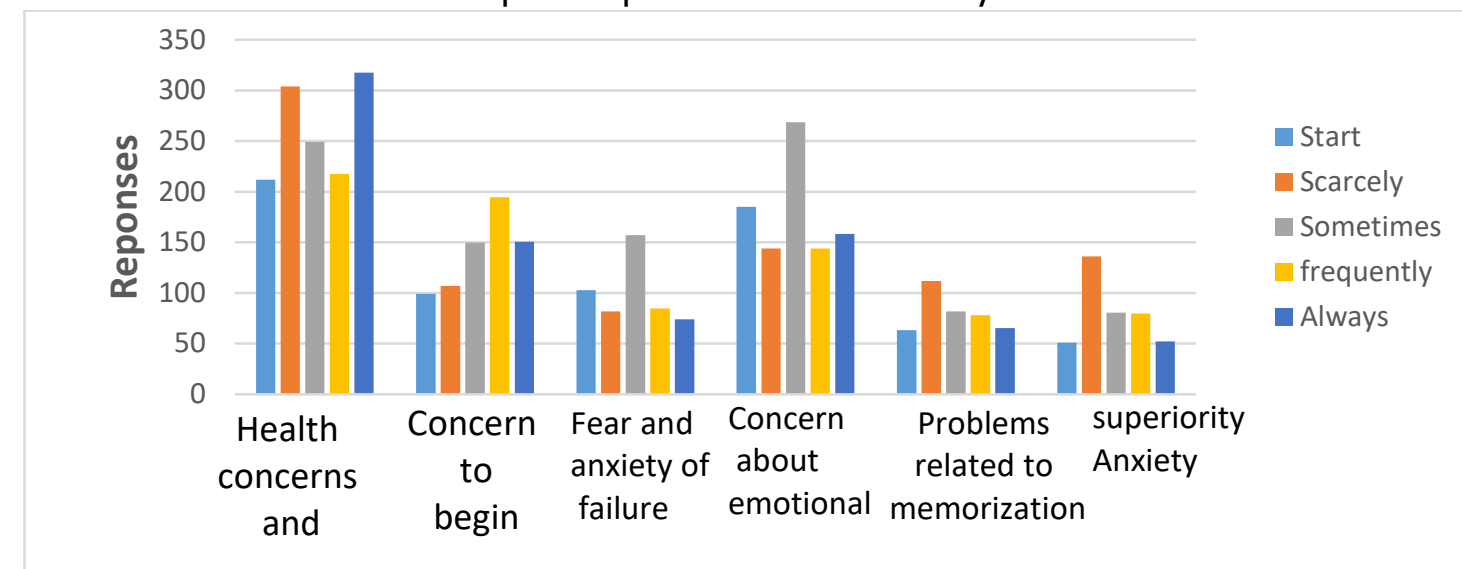

Sample Response Rate to Anxiety Scale

Table (4 - 10) shows that the highest response rate of second - secondary students to (always) is in health and school anxiety. Their responses to (often) are in exam anxiety. Their responses to (sometimes) are in anxiety of emotional and physical problems. Their responses to (rarely) are in anxiety of memory and memorization problems as well as excellence anxiety. Eventually, their responses to (never) are in fear and anxiety of failure.

Fourth Question: What is the social media contribution to the prediction of the aspiration level among a sample of second - secondary students in Irbid?

For the purpose of answering this question, the following hypothesis was formulated: " There is a social media contribution to the prediction of the aspiration level among a sample of second secondary students in Irbid".

To answer this question, a Stepwise Multiple Regression Analysis was conducted to reveal the extent of the social media contribution to the prediction of aspiration among both genders. Table (4 - 11) shows the results of this analysis.

\begin{tabular}{|l|l|l|l|l|l|l|}
\hline \multicolumn{7}{|c|}{ Table (4 - 11) } \\
\hline \multicolumn{2}{|c|}{ Results of the Stepwise Multiple Regression Analysis of the Contribution of Each Dimension of } \\
the Social Media Scale to the Prediction of Aspiration \\
\begin{tabular}{|l} 
Dependent \\
Variable
\end{tabular} & \multicolumn{1}{|c|}{$\begin{array}{c}\text { Predictors } \\
\text { Aspiration }\end{array}$} & $\begin{array}{c}\text { Coefficient } \\
\text { B }\end{array}$ & $\begin{array}{c}\text { Multiple } \\
\text { Correlation } \\
\mathrm{R}\end{array}$ & $\begin{array}{c}\text { Variance } \\
\text { R2 }\end{array}$ & $\mathrm{F}$ & $\begin{array}{c}\text { Level of } \\
\text { Significance }\end{array}$ \\
& $\begin{array}{l}\text { Purpose of } \\
\text { Account Usage }\end{array}$ & 0.26 & 0.34 & 0.12 & 72.752 & $0.000^{*}$ \\
\cline { 2 - 8 } & $\begin{array}{l}\text { Topics Attracting } \\
\text { my Attention }\end{array}$ & 0.14 & 0.38 & 0.16 & 51.490 & $0.000^{*}$ \\
\hline
\end{tabular}

$0.0001>P *$ 
Table (4 - 11) shows that the dimensions (the purpose of account usage and the topics attracting my attention on social media sites) in the aggregate were about $16 \%$ of the variance in the aspiration level. The dimension of the purpose of account usage was $12 \%$ and the dimension of the topics attracting my attention on social media sites was $4 \%$. Therefore, there is statistically significant contribution of the dimensions (the purpose of account usage and the topics attracting my attention on social media sites) to the prediction of aspiration at the level of significance $(0.0001>\mathrm{P})$. With regard to other dimensions, the table shows that they did not contribute statistically to the prediction of aspiration. The hypothesis was accepted according to the results.

Fifth Question: What is the social media contribution to the prediction of depressive symptoms among a sample of second - secondary students in Irbid?

For the purpose of answering this question, the following hypothesis was formulated: "There is a social media contribution to the prediction of depressive symptoms among a sample of second secondary students in Irbid".

To answer this question, a Stepwise Multiple Regression Analysis was conducted to reveal the extent of the social media contribution to the prediction of depressive symptoms among both genders. Table (4 - 12) shows the results of this analysis.

\begin{tabular}{|l|l|l|l|l|l|l|}
\hline \multicolumn{7}{|c|}{ Table (4 - 12) } \\
\hline \multicolumn{2}{|c|}{$\begin{array}{c}\text { Results of the Stepwise Multiple Regression Analysis of the Contribution of Each Dimension of } \\
\text { the Social Media Scale to the Prediction of Depressive Symptoms }\end{array}$} \\
\hline $\begin{array}{c}\text { Dependent } \\
\text { Variable }\end{array}$ & \multicolumn{1}{|c|}{ Predictors } & $\begin{array}{c}\text { Coefficient } \\
\text { B }\end{array}$ & $\begin{array}{c}\text { Multiple } \\
\text { Correlation } \\
\mathrm{R}\end{array}$ & $\begin{array}{c}\text { Variance } \\
\text { R2 }\end{array}$ & $\mathrm{F}$ & \multicolumn{1}{c|}{$\begin{array}{c}\text { Level of } \\
\text { Significance }\end{array}$} \\
\hline $\begin{array}{l}\text { Depressive } \\
\text { Symptoms }\end{array}$ & $\begin{array}{l}\text { Topics Attracting } \\
\text { my Attention }\end{array}$ & 0.20 & 0.42 & 0.18 & 117.71 & 0.000 \\
\cline { 2 - 8 } & $\begin{array}{l}\text { Purpose of } \\
\text { Account Usage }\end{array}$ & -0.03 & 0.44 & 0.20 & 66.484 & 0.000 \\
\hline
\end{tabular}

$0.0001>\mathrm{P}^{*}$

Table (4 - 12) shows that the dimensions (the topics attracting my attention on social media sites and the purpose of account usage) in the aggregate were about $20 \%$ of the variance in the level of depressive symptoms. The dimension of the topics attracting my attention was $18 \%$ and the dimension of the purpose of account usage was $2 \%$. Therefore, there is statistically significant contribution of the dimensions (the topics attracting my attention on social media sites and the purpose of account usage) to the prediction of depressive symptoms at the level of significance $(0.0001>\mathrm{P})$. With regard to other dimensions, the table shows that they did not contribute statistically to the prediction of depressive symptoms. The hypothesis was accepted according to the results.

Sixth Question: What is the social media contribution to the prediction of anxiety among a sample of second - secondary students in Irbid?

For the purpose of answering this question, the following hypothesis was formulated: " There is a social media contribution to the prediction of anxiety among a sample of second - secondary students in Irbid ". 
INTERNATIONAL JOURNAL OF ACADEMIC RESEARCH IN BUSINESS AND SOCIAL SCIENCES

Vol. 8, No. 11, Nov, 2018, E-ISSN: 2222-6990 @ 2018 HRMARS

To answer this question, a Stepwise Multiple Regression Analysis was conducted to reveal the extent of the social media contribution to the prediction of anxiety among both genders. Table (4 13) shows the results of this analysis.

Table (4 - 13)

Results of the Stepwise Multiple Regression Analysis of the Contribution of Each Dimension of the Social Media Scale to the Prediction of Anxiety

\begin{tabular}{|l|l|l|l|l|l|l|}
\hline $\begin{array}{c}\text { Dependent } \\
\text { Variable }\end{array}$ & \multicolumn{1}{|c|}{ Predictors } & $\begin{array}{c}\text { Coefficient } \\
\text { B }\end{array}$ & $\begin{array}{c}\text { Multiple } \\
\text { Correlation } \\
\text { R }\end{array}$ & $\begin{array}{c}\text { Variance } \\
\text { R2 }\end{array}$ & F & \multicolumn{1}{|c|}{$\begin{array}{c}\text { Level of } \\
\text { Significance }\end{array}$} \\
\hline Anxiety & $\begin{array}{l}\text { Duration of Social } \\
\text { Media Usage }\end{array}$ & 0.10 & 0.35 & 0.13 & 78.744 & 0.000 \\
\cline { 2 - 7 } & $\begin{array}{l}\text { Purpose of } \\
\text { Account Usage }\end{array}$ & 0.09 & 0.38 & 0.15 & 47.244 & 0.000 \\
\hline
\end{tabular}

$0.0001>\mathrm{P} *$

Table (4 - 13) shows that the dimensions (the duration of social media usage and the purpose of account usage) in the aggregate were about $15 \%$ of the variance in the level of anxiety. The dimension of the duration of social media usage was $13 \%$ and the dimension of the purpose of account usage was $2 \%$. Therefore, there is statistically significant contribution of the dimensions (the duration of social media usage and the purpose of account usage) to the prediction of anxiety at the level of significance $(0.0001>\mathrm{P})$. With regard to other dimensions, the table shows that they did not contribute statistically to the prediction of anxiety. The hypothesis was accepted according to the results.

\section{Study Recommendations}

According to the study results, the researcher recommends the following:

\section{- Decision Makers}

1. Increasing the use of technological means and strategies that enable to inform the opportunities and aspirations of others.

2. Issuing an instructional leaflet by the Ministry of Education and distributing it within schools, which explains how to best use the social media and determines the hours of use.

3. Preparing educational programs that encourage the use of encouragement and achieve aspirations among secondary school students due to their significant impact on the students' personality.

\section{- School Staff}

4. Developing and paying attention to students' aspirations through training and involving them with success stories within schools.

5. Spreading awareness among school students about the importance of social media as one of the requirements of the technological age through distributing scientific publications and holding symposia and meetings. 
INTERNATIONAL JOURNAL OF ACADEMIC RESEARCH IN BUSINESS AND SOCIAL SCIENCES

Vol. 8, No. 11, Nov, 2018, E-ISSN: 2222-6990 C 2018 HRMARS

\section{- Researchers and Interested Parties}

6. Conducting future studies for different age groups regarding social media use in order to identify the negative impacts of this technology and take advantage of its positive impacts.

7. Encouraging psychologists and sociologists to involve parents in raising awareness of the social media use resulting in depression and anxiety.

\section{- Family}

8. The family should provide a calm atmosphere away from family arguments that create problems and mental disorders.

9. Determining a calm and comfortable place for studying that is calm and comfortable as well as helping students in the matters they need.

10. Avoiding speech that would offend and underestimate the student.

11. Parents should support their student's exam preparation, calm her / him out of fear and tension, reassure her / him upon completion of the exam and give her / him the necessary support and energy.

\section{- Students}

12. The student should not use social media for long periods of time, which results in the lack of motivation to studying.

13. Avoiding the stressful atmosphere within the family.

14 - Avoiding a collective study using social media because it becomes a means of exchanging dialogues and interactions in subjects beyond the specific framework of study.

15. The student should prepare a schedule for study times, rest times and internet usage.

\section{ACKNOWLEDGEMENT}

Special thanks to Research Management, Innovation \& Commercialization Centre (RMIC) and University Sultan Zainal Abidin (UniSZA) for funding this research

\section{References}

Ibrahim, N. (2003). The relationship between job security and the aspiration level among managers working in the headquarters of the ministries of the Palestinian National Authority and the impact of some demographic variables on them. Unpublished Master Thesis, An-Najah National University, Nablus.

Al-Aswad, F. (2003). The relationship between creative thinking and both the causal attribution and the aspiration level among the elementary fifth and sixth grade students. A study on self concept and level of anxiety and aspiration among university students in Palestine. Unpublished Doctoral Dissertation, Al - Aqsa University, Gaza.

Badr, S. (2016). Digital Statistics in the world, the Middle East and Egypt 2016. They are available on the following website: https://ae.linkedin.com/pulse/2016-shereen-badr dated 21/3/2018.

Al-twaijri, A. (2002). Specific Social Variables and Social Aspiration Patterns. Unpublished Doctoral Dissertation, Riyadh, King Abdulaziz Public Library.

Jarar, Layla (2012). Facebook and the Arab youth. Kuwait: Dar Al Falah for Publishing and Distribution. 
INTERNATIONAL JOURNAL OF ACADEMIC RESEARCH IN BUSINESS AND SOCIAL SCIENCES

Vol. 8, No. 11, Nov, 2018, E-ISSN: 2222-6990 @ 2018 HRMARS

Dagher, A. (2010). The educational, social and economic problems facing private secondary school students in Jordan from student and their parents' point of view. Unpublished Master Thesis, Amman Arab University, Amman, Jordan.

Al- Thawad, Al Jawhara (2002). The relationship between the discipline and the aspiration level among some Saudi and Egyptian university students. Arab Studies in Psychology, 1 (3), 119 $-152$.

Al- Zahrani, A. (2009). The relationship between the perception of parental acceptance - rejection and the aspiration level among middle school students in Jeddah. Unpublished Master Thesis, Umm Al -Qura University, Makkah.

Suleiman, S. (1984). The relationship between the aspiration levels and both the self - concept and academic achievement among university students. Unpublished Doctoral Dissertation, Ain Shams University, Egypt.

Shihri, H. (2012). The impact of the electronic networks use on social relations: Facebook and Twitter model. Unpublished Master Thesis, King Abdulaziz University, Jeddah, Saudi Arabia.

Tayeb, M. (1994). Mental Health Principles. Alexandria: The House of University Knowledge (Dar Al Ma'rifa Al Jami'iyah).

Aqel, F. (2003). Dictionary of Psychology. Cairo: Shuaa for Publishing and Science.

Sayed,A.W. (1992). A study on the relationship between the aspiration level and some mental abilities and emotional characteristics of personality during some growth stages. Unpublished Master Thesis, Minia University, Egypt.

Imran, T. (2013). Infographic: The Use of Social Media Sites in the Middle East. It is available on the following website: https://www.tech-wd.com/wd/2013/11/01 dated 21/3/2018.

Gaddafi, R. (2000). Growth Psychology: Childhood and Adolescence. Alexandria: Modern University Office.

Qenaoui, H. (1992). The Psychology of Adolescence. Cairo: The Anglo - Egyptian Bookshop.

Al- Majali, F. (2007). The impact of the internet usage on social relations among university youth: a field study. Manara, 13 (7), 160 - 197.

Al- Muthaffar, A. (2015). Youth education and children protection from the time effects. Beirut: Al Basayr House and Library for Printing, Publishing and Distribution.

Muawad, M., \& Abdulathim, S. (2005). Aspiration Level Scale. Cairo: The Anglo -Egyptian Bookshop.

Mansour, M. (2012). The impact of social networks on the audience: A comparative study of social sites and websites "Al Arbia model". Master Degree in Media and Communication Introduction to the Arab Open Academy in Denmark, Council of the Faculty of Arts and Education.

Adler, A. (1998). What life could mean to you. Minnesota: Hazelden Foundation.

Andreassen, C., Billieux, J., Griffiths, M., Kuss, D., Demetrovics, Z. \& et al., (2016). The relationship between addictive use of social media and video games and symptoms of psychiatric disorders: A large-scale cross-sectional study. Psychology of Addictive Behaviors, 30 (2), 252-262.

Barlow, D. (1999). Abnormal psychology. Pacific grove, CA: Brooks/Cole.

Bauer, J., McAdams, D. \& Sakaeda, A. (2005). Interpreting the good life: Growth memories in the lives of mature, happy people. Journal of Personality and Social Psychology, 88, 203-217. 
INTERNATIONAL JOURNAL OF ACADEMIC RESEARCH IN BUSINESS AND SOCIAL SCIENCES

Vol. 8, No. 11, Nov, 2018, E-ISSN: 2222-6990 @ 2018 HRMARS

Beck, A. (1991). Cognitive therapy. A 30-year retrospective. American Psychologist, 46 (4), 368-375.

Beck, A. \& Emery, G .(1985). Anxiety disorders and phobias: A cognitive perspective. New York: Basic Books.

Becker, M., Alzahabi, R. \& Hopwood, C. (2013). Media multitasking is associated with symptoms of depression and social anxiety. Cyberpsychology, Behavior \& Social Networking, 16(2), 132135.

Fridman, K .( 2003). Adolescent psychiatry. New York: Pocket Books.

Kasser, T. \& Ryan, R. (2001). Be careful what you wish for: Optimal functioning and the relative attainment of intrinsic and extrinsic goals. In P. Schmuck \& K. M. Sheldon (Eds.), Life goals and wellbeing: Towards a positive psychology of human striving (pp. 116-131). Goettingen, Germany: Hogrefe \& Hube

Lewin, K. (1939). Field theory and experiment in social psychology. American Journal of Sociology, 44 (6), 868-896.

Lin, L., Sidani, J., Shensa, A., Radovic, A. Miller, E., Colditz, J., \& et al., (2016). Association between social media use and depression among U.S. young adults. Depression \& Anxiety, 33, 323331.

Myers, D .(2000). The funds, friends, and faith of happy people. American Psychologist, 55 (1), 56-67.

Ophir, E., Nass, C. \& Wagner, A. (2009). Cognitive control in media multitasks. PNAS Proceedings of the National Academy of Sciences of the United States of America,106(37),15583-7.

Pantic, I., Damjanovic, A., Todorovic, J., Topalovic, D., Jovic, D., Ristic, S., \& et al., (2012). Association between online social networking and depression in high school students: Behavioral physiology viewpoint. Psychiatria Danubina, 24 (1), 90-93.

Park, M., Cha, C. \& Cha, M. (2012). Depressive moods of users captured in twitter. In Proc. ACM SIGKDD Workshop on Healthcare Informatics (HI-KDD).

Rude, S., Gortner, E. \& Pennebaker, J. (2004). Language use of depressed and depression-vulnerable college students. Cognition and Emotion, 18 (4), 1121-1133.

Stanger, R. (1961). Psychology of personality. New York: Megow-hillbook. co. inc.

Strickland, A. (2014). Exploring the effects of social media use on the mental health of young adults. Ph.D thesis, University of central Florida, Florida, USA.

Taylor, J. (1951). The relationship of anxiety to the conditioned eyelid response. J. exp. Psychol, 41, 81-92.

Walker, G. \& Roberts, M. (1983). Handbook of clinical-child psychology. New York: John Wiley\& Sons. Woods, H. (2015). Study: Pressure to be on social media 24/7 causes anxiety, sleep problems in teens. Retrieved from website: http://fox8.com/2015/09/14/study-pressure-to-be-on-socialmedia-247-causes-anxiety-sleep-problems-in-teens/ 08.08.2017. 